\title{
Polybrominated Diphenyl Ethers in Mudsnails (Cipangopaludina cahayensis) and Sediments from an Electronic Waste Recycling Region in South China
}

\author{
Z. Z. Yang $\cdot$ X. R. Zhao $\cdot$ Z. F. Qin $\cdot$ S. Fu \\ X. H. Li - X. F. Qin · X. B. Xu - Z. X. Jin
}

Received: 31 March 2008/Accepted: 17 October 2008/Published online: 4 November 2008

(C) Springer Science+Business Media, LLC 2008

\begin{abstract}
Mudsnails and sediments from an electronic waste recycling region in South China were chosen to study the polybrominated diphenyl ethers (PBDEs) bioavailability of mudsnail in different ambient levels. Significant $(p<0.05) \quad$ correlations of biota-sediment accumulation factor (BSAF) versus the reciprocal of PBDE concentration in sediment (1/Sed) occurred in all quantitative PBDE congeners except BDE-209, showed that the BSAFs of PBDEs in mudsnails were increased with reciprocal increasing ambient levels. The BDE-183 correlation of mudsnail versus sediment $(r=0.580)$ was much lower than the correlation of BDE-209 versus BDE-183 in mudsnails $(r=0.812)$, indicated the main source of BDE183 in mudsnails was from the debromination of higher brominated PBDEs.
\end{abstract}

Keywords Polybrominated diphenyl ethers (PBDEs) .

Mudsnail · Sediment · Biota-sediment accumulation factor (BSAF)

Polybrominated diphenyl ethers (PBDEs) are brominated flame retardants (BFRs) which are widely used as additive

Z. Z. Yang · X. R. Zhao - Z. F. Qin . S. Fu •

X. H. Li · X. F. Qin · X. B. Xu (ه)

State Key Laboratory of Environmental Chemistry and Ecotoxicology, Research Center for Eco-Environmental

Sciences, Chinese Academy of Sciences, Post Office Box 2871, 18 Shuangqing Road, Haidian District, Beijing 100085, People's

Republic of China

e-mail: xuxb@rcees.ac.cn

Z. X. Jin

Taizhou University, Taizhou City 317000, Zhejiang Province,

People's Republic of China components in a range of consumer products, such as computers, televisions, textiles, furniture, and other building materials (Birnbaum and Staskal 2004). They can be dissolved in materials and then leached into the environment and entered biota (Strandberg et al. 2001). The electronic waste (e-waste) recycling especially uncontrolled dismantling aggravated the process (Julander et al. 2005). So PBDEs become ubiquitous in the environment (Ueno et al. 2004). Furthermore, most toxicological studies have shown that serious health consequences, such as thyroidogenic, estrogenic, and hepatic effects as well as neurodevelopmental disorders, could result from prolonged exposure to PBDEs (Darnerud et al. 2001). Two of the three commercial PBDE mixtures ("penta-BDE" and "octa-BDE") have been banned by the European Union and several U.S. states. Currently, the "deca-BDE" commercial mixtures are still heavy used, and there is no regulation for the usage and disposal of deca-BDE.

Because of their ubiquity and potential toxicity, fish (Johnson and Olson 2001), birds (Voorspoels et al. 2006), bird eggs (Jonathan et al. 2006), and other biota (Pettersson et al. 2004) had been used to monitor the distribution of PBDEs in the environment. It was reported that lower (tetra- and penta-) PBDEs accumulated and biomagnified in biota, while the higher congeners (deca-) were prevalent in aquatic environments and sediments (Martin et al. 2004). And dietary exposure studies revealed that the bioavailability of deca-BDE had produced a range of results (Huwe and Smith 2007). However, there are few studies on the PBDEs bioavailability of biomonitor under different ambient levels (Sellström et al. 1998). In this work, we chose mudsnails (Cipangopaludina cahayensis) and sediments from an e-waste recycling region in South China to study the PBDEs bioavailability of mudsnail in different ambient levels. We aimed the bioconcentration, 
congeners distribution and source of PBDEs in mudsnails and sediments.

\section{Materials and Methods}

PBDE analytical standard EPA Method 1614 native PAR stock solution EO-5278 (unlabeled BDE-28, 47, 99, 100, 153, 154, 183, 209), method 1614 labeled surrogate stock solution EO-5277 ( ${ }^{13} \mathrm{C}_{12}$ labeled BDE-28, 47, 99, 100, 153, $154,183,209)$ and method 1614 labeled injection internal stock solution EO-5275 $\left({ }^{13} \mathrm{C}_{12}\right.$ labeled CB-52, 138) was purchased from Cambridge Isotope Laboratories, Inc. (Andover, MA). Hexane and dichloromethane used for the extraction and cleanup procedures were pesticide grade (J. T. Baker, USA), and other solvents and reagents were of analytical grade.

Owing to e-waste imports and multiform recycling activities, soils, sediments, and fish were highly contaminated by PBDEs in e-waste recycling regions in South China (Luo et al. 2007), such as Guiyu of Guangdong Province and Taizhou of Zhejiang Province. In this work, ditches of four sites in Taizhou of Zhejiang Province were chosen to collect mudsnails and sediments in November of 2006. For each site, mudsnails were selected by them avoirdupois (over $3 \mathrm{~g}$ ) and only edible parts (rinsed with distilled water if necessary) were separated and well homogenized in a tissue homogenizer, sediments around mudsnails were collected and mixed as one sediment sample. After been freeze-dried, each sediment was ground, sieved to 40 mesh completely. Then they were preserved frozen at $-20^{\circ} \mathrm{C}$ until analysis.

One gram of dried sediment or dried mudsnail sample was ground with anhydrous sodium sulfate into free-flowing powder. The samples were extracted with $200 \mathrm{~mL}$ of hexane/dichloromethane $(1: 1, \mathrm{v} / \mathrm{v})$ in Soxhlet extraction mode for $24 \mathrm{~h}$. All samples were spiked with eight ${ }^{13} \mathrm{C}_{12}$ labeled PBDE recovery standards (EO-5277) prior to extraction and cleanup. Then the concentrated extracts were cleaned on a 15-mm i.d. column packed, from the bottom to top, with $1 \mathrm{~g}$ activated silica gel, $3 \mathrm{~g}$ basic silica gel (EPA Method 1614, Sect. 7.5.1.3), $1 \mathrm{~g}$ activated silica gel, $4 \mathrm{~g}$ acid silica gel ( $44 \%$ concentrated sulfuric acid, w/ w), $4 \mathrm{~g}$ acid silica gel ( $22 \%$ concentrated sulfuric acid, w/ w), $1 \mathrm{~g}$ activated silica gel and $1 \mathrm{~cm}$ anhydrous sodium sulfate. The elution was $70 \mathrm{~mL}$ of hexane: dichloromethane (1:1). Then another column (8-mm i.d.) containing $2 \mathrm{~g}$ silver nitrate $\left(\mathrm{AgNO}_{3}\right)$ silica $(10 \%, \mathrm{w} / \mathrm{w}), 2 \mathrm{~g}$ activated silica gel and $1 \mathrm{~cm}$ anhydrous sodium sulfate was used. PBDEs were separated from PCBs by two fractions: $40 \mathrm{~mL}$ hexane for PCBs and $40 \mathrm{~mL}$ hexane/dichloromethane $(1: 1$, $\mathrm{v} / \mathrm{v})$ for PBDEs. The PBDEs fraction was collected and reduced to $30 \mu \mathrm{L}$ under a gentle $\mathrm{N}_{2}$ stream. Then, ${ }^{13} \mathrm{C}_{12}$ labeled injection internal standards, EO-5275, was added prior to the GC injection. Throughout the extraction, cleanup and analysis procedure, the analytes were protected from light by wrapping the containers with aluminum foil or by using amber glassware. The lipid content of mudsnail was determined gravimetrically by evaporating an aliquot of the extract to constant weight, and the organic matter of sediment was estimated by weight loss-on-ignition (LOI).

The samples were analyzed on an Agilent 6890 series gas chromatograph coupled with an Agilent 5973 mass spectrometer. For the analysis of BDE-28, 47, 99, 100, 153, 154,183 , the mass spectrometer was operated with electron impact ionization (EI) source in SIM mode and a DB-5MS (30 $\mathrm{m} \times 0.25 \mathrm{~mm}$ i.d., $0.25 \mu \mathrm{m}$ film thickness) capillary column was used. The temperature of the MS ion source (electron energy $70 \mathrm{eV}$ ) and transfer line were kept at 230 and $300^{\circ} \mathrm{C}$, respectively. The GC oven temperature program was carried out as follows: initial temperature $100^{\circ} \mathrm{C}$ held for $1 \mathrm{~min}$, increased to $150^{\circ} \mathrm{C}$ at $10^{\circ} \mathrm{C} / \mathrm{min}$ held $5 \mathrm{~min}$, and then to $280^{\circ} \mathrm{C}$ at $5^{\circ} \mathrm{C} / \mathrm{min}$, to $290^{\circ} \mathrm{C}$ at $10^{\circ} \mathrm{C} / \mathrm{min}$, held for $15 \mathrm{~min}$. Helium was used as the carrier gas at a flow rate of $1 \mathrm{~mL} / \mathrm{min}$. For the determination of BDE-209, the mass spectrometer was operated with negative chemical ionization (NCI) in the selected ion monitoring (SIM) mode and a DB-5 MS (15 $\mathrm{m} \times 0.25 \mathrm{~mm}$ i.d., $0.25 \mu \mathrm{m}$ film thickness) capillary column was used. Methane was used as a chemical ionization moderating gas and helium as the carrier gas at a flow rate of $1.5 \mathrm{~mL} / \mathrm{min}$. The ion source and interface temperatures were set to 150 and $300^{\circ} \mathrm{C}$, respectively. The temperature program was from $80^{\circ} \mathrm{C}$ (1 min) to $200^{\circ} \mathrm{C}$ at $10^{\circ} \mathrm{C} / \mathrm{min}$, and to $300^{\circ} \mathrm{C}$ (held $15 \mathrm{~min}$ ) at $20^{\circ} \mathrm{C} / \mathrm{min}$. Both experiments were used the splitless injection mode and injected $1 \mu \mathrm{L}$ (injector temperature $265^{\circ} \mathrm{C}$ ) with a solvent delay set at $6 \mathrm{~min}$.

Eight PBDE congeners (BDE-28, 47, 99, 100, 153, 154, 183, 209) were quantified using ${ }^{13} \mathrm{C}_{12}$ isotope dilution methods. Under the EI-MS conditions, the molecular ions $\left([\mathrm{M}+2]^{+}\right.$or $\left.[\mathrm{M}+4]^{+}\right)$were selected for BDE-28 and BDE47, fragment ions resulting from the loss of $\mathrm{Br}_{2}$ ([M$\left.\mathrm{Br}_{2}+2\right]^{+}$or $\left[\mathrm{M}-\mathrm{Br}_{2}+4\right]^{+}$) for BDE-99, 100, 153, and 154, and $\left(\left[\mathrm{M}-\mathrm{Br}_{2}+4\right]^{+}\right.$or $\left.\left[\mathrm{M}-\mathrm{Br}_{2}+6\right]^{+}\right)$for BDE-183. And the fragment ions $\left(\left[\mathrm{C}_{6} \mathrm{Br}_{5} \mathrm{O}\right]^{-}\right)$were monitored for BDE-209 and ${ }^{13} \mathrm{C}_{12}$ labeled BDE-209 under NCI-MS conditions. The monitored ions $\mathrm{m} / \mathrm{z}$ of analyzed PBDE congeners were listed in Table 1. Quality control was done by regular analyses of procedural blanks, and regular injection of solvent blanks and standards. All results of target analysis reported in the study were means of duplicate analyses, and the residue concentrations in samples below quantificational limits were regarded to be equal to zero in calculation of sum, means and so on. The limit of quantifications (LOQ) defined as the mean procedural blank 
Table 1 The monitored ion $\mathrm{m} / \mathrm{z}$ of unlabeled and ${ }^{13} \mathrm{C}_{12}$ labeled PBDE congeners

\begin{tabular}{lll}
\hline Name & \multicolumn{2}{l}{$\mathrm{m} / \mathrm{z}$ of monitored ion } \\
\cline { 2 - 3 } & Unlabeled & ${ }^{13} \mathrm{C}_{12}$ labeled \\
\hline BDE-28 & $405.8 / 407.8$ & $417.8 / 419.8$ \\
BDE-47 & $483.7 / 485.7$ & $495.7 / 497.7$ \\
BDE-99 & $403.8 / 405.8$ & $415.8 / 417.8$ \\
BDE-100 & $403.8 / 405.8$ & $415.8 / 417.8$ \\
BDE-153 & $481.7 / 483.7$ & $493.7 / 495.7$ \\
BDE-154 & $481.7 / 483.7$ & $493.7 / 495.7$ \\
BDE-183 & $561.6 / 563.6$ & $573.6 / 575.6$ \\
BDE-209 & $484.7 / 486.7$ & $494.7 / 496.7$ \\
\hline
\end{tabular}

value plus a safety margin of $3 \times$ standard deviation $(\mathrm{SD})$ of the procedural blanks were $0.01-0.1 \mathrm{ng} / \mathrm{g}$ dry weight for BDE-28, 47, 99, 100, 153, 154, and 183 in EI-MS mode, and $0.1 \mathrm{ng} / \mathrm{g}$ dry weight for deca-BDE in NCI-MS mode. The recovery rates of ${ }^{13} \mathrm{C}_{12}$ labeled $\mathrm{BDE}-209$ spiked to sediment and mudsnail samples ranged from 60 to $90 \%$. For the other ${ }^{13} \mathrm{C}_{12}$ labeled PBDEs, it were $75-110 \%$.

\section{Results and Discussion}

The concentrations of 8 target PBDE congeners and $\sum$ PBDE (sum of the BDE-28, 47, 99, 100, 153, 154, 183, 209) in sediment and mudsnail samples (ng/g dry weight) of the four sites were given in Table 2. The levels and patterns of PBDEs in sediments showed significant differences with mudsnails. In the sediments, with the concentrations of $\sum$ PBDE (sum of the BDE-28, 47, 99, $100,153,154,183,209)$ ranged from 15.05 to $3526 \mathrm{ng} / \mathrm{g}$ (dry weight), the dominant part of PBDEs was BDE-209 accounted for $80.14-99.55 \%$, which were similar with the sediments of Pearl River Delta (Mai et al. 2005). But in the mudsnail samples, BDE-209 had wide range from not detected in site 1 to $9.50 \mathrm{ng} / \mathrm{g}$ (dry weight) in site 4
(36.59\%). Consistent with other POPs, the concentrations of PBDEs in mudsnails were increased with increasing ambient levels. The biota-sediment accumulation factor (BSAF), defined as the ratio of the lipid-normalized concentration of a chemical in an organism to the organic carbon (OC) - normalized concentration of the chemical in sediment, was calculated for individual PBDE congeners (Table 3). The lowest BSAFs of BDE-209 in all sties indicated the low bioavailability of this highest brominated PBDE, and the highest BSAFs of other PBDE congeners were found in site 1 which was lightest contaminated by PBDEs in sediment. Significant $(p<0.05)$ correlations of BSAF versus the reciprocal of PBDE concentration in sediment $(1 / \mathrm{Sed})$ occurred in all quantitative PBDE congeners except BDE-209, showed that the BSAFs of PBDEs in mudsnails were increased with reciprocal increasing ambient levels in Taizhou e-waste recycling region.

To investigate potential sources and distribution, Pearson correlation analyses were performed for PBDE congeners in sediments and mudsnails (Table 4). For sediments, significant correlations existed among tri-, tetra-, penta-, and hexa- BDE such as BDE-28, 47, 99, 100, 153, and 154. Although BDE-183 and 209 showed relatively lower correlations with the lower brominated PBDE congeners, the correlation coefficients of BDE-209 versus BDE-183 and BDE-183 versus BDE-153, 154 were higher than they versus other lower brominated PBDE congeners. Moon et al. (2007) suggested this similar pattern due to the sources of lower-molecular-weight PBDEs differed from the sources of BDE-209 or BDE-183 and the differences in the partitioning between the lower brominated PBDE congeners and the more brominated PBDE congeners in the aquatic environment. In addition, we suggested this pattern maybe also imply the different transporting manner of the lower brominated PBDE congeners from the more brominated PBDE congeners in the aquatic environment. In mudsnails, the relatively higher correlation coefficients were occurred among immediate bromine atom number substituted congeners such as tri-BDE (BDE-28) versus
Table 2 The concentrations of eight target $\mathrm{PBDE}$ congeners and $\sum$ PBDE (sum of the BDE28, 47, 99, 100, 153, 154, 183, 209 ) in sediment and mudsnail samples (ng/g dry weight) of the four sites

Sed: sediment; Mud: mudsnail; ND: not detected

\begin{tabular}{|c|c|c|c|c|c|c|c|c|}
\hline \multirow[t]{2}{*}{ Name } & \multicolumn{2}{|l|}{ Site 1} & \multicolumn{2}{|l|}{ Site 2} & \multicolumn{2}{|l|}{ Site 3} & \multicolumn{2}{|l|}{ Site 4} \\
\hline & Sed & Mud & Sed & Mud & Sed & Mud & Sed & Mud \\
\hline BDE-28 & 0.04 & 0.49 & 46.65 & 19.20 & 0.76 & 1.07 & 0.77 & 0.80 \\
\hline BDE-47 & 0.16 & 6.87 & 296.49 & 23.08 & 3.29 & 6.75 & 3.86 & 5.19 \\
\hline BDE-100 & 0.01 & 0.19 & 50.99 & 7.16 & 0.77 & 2.33 & 0.45 & 2.00 \\
\hline BDE-99 & 0.13 & 2.27 & 254.38 & 13.59 & 4.53 & 6.39 & 4.03 & 4.27 \\
\hline BDE-154 & 0.02 & 0.18 & 14.47 & 1.73 & 1.28 & 0.95 & 0.55 & 0.63 \\
\hline BDE-153 & 0.03 & 0.19 & 52.93 & 4.01 & 2.15 & 1.80 & 0.74 & 1.78 \\
\hline BDE-183 & 0.01 & 0.06 & 11.13 & 1.09 & 6.19 & 1.30 & 5.42 & 1.79 \\
\hline BDE-209 & 14.66 & ND & 2934.36 & 1.17 & 895.77 & 2.51 & 3510.19 & 9.50 \\
\hline$\sum$ PBDEs & 15.05 & 10.24 & 3661.39 & 71.01 & 914.74 & 23.11 & 3526.00 & 25.96 \\
\hline
\end{tabular}


Table 3 PBDE congeners' BSAFs of mudsnails in four sites and the BSAF versus $1 /$ (sediment concentration) correlations of congeners

\begin{tabular}{|c|c|c|c|c|c|}
\hline \multirow[t]{2}{*}{ Name } & \multicolumn{4}{|l|}{ BSAF } & \multirow{2}{*}{$\begin{array}{l}\text { Correlation of } \\
\text { BSAF versus } 1 / \mathrm{Sed}\end{array}$} \\
\hline & Site 1 & Site 2 & Site 3 & Site 4 & \\
\hline BDE-28 & 4.00 & 0.16 & 0.64 & 0.73 & $0.98^{*}$ \\
\hline BDE-47 & 12.27 & 0.03 & 0.93 & 0.94 & $1.00 * *$ \\
\hline BDE-100 & 5.85 & 0.05 & 1.38 & 3.11 & $1.00 * *$ \\
\hline BDE-99 & 4.98 & 0.02 & 0.64 & 0.74 & $1.00 * *$ \\
\hline BDE-154 & 3.18 & 0.05 & 0.34 & 0.80 & $0.99 * *$ \\
\hline BDE-153 & 1.93 & 0.03 & 0.38 & 1.68 & $1.00 * *$ \\
\hline BDE-183 & 1.21 & 0.04 & 0.10 & 0.23 & $0.99 *$ \\
\hline BDE-209 & NA & 0.0002 & 0.0013 & 0.0019 & 0.78 \\
\hline
\end{tabular}

* Correlation is significant at the 0.05 level (2-tailed)

** Correlation is significant at the 0.01 level (2-tailed)

Sed: sediment; NA: not available

Table 4 Pearson product-moment correlation coefficients among PBDE congeners in mudsnails (in roman) and sediments (in boldface and italics) of four sites and the congener correlation of mudsnail versus sediment

\begin{tabular}{|c|c|c|c|c|c|c|c|c|c|}
\hline Name & BDE-28 & BDE-47 & BDE-100 & BDE-99 & BDE-154 & BDE-153 & BDE-183 & BDE-209 & $\begin{array}{l}\text { Correlation of Mud } \\
\text { versus Sed }\end{array}$ \\
\hline BDE-28 & & $1.000 * *$ & $1.000 * *$ & $1.000 * *$ & $0.998 * *$ & $1.000 * *$ & 0.806 & 0.451 & $1.000 * *$ \\
\hline BDE-47 & $0.995 * *$ & & $1.000 * *$ & $1.000 * *$ & $0.998 * *$ & $1.000 * *$ & 0.804 & 0.449 & $0.995^{* *}$ \\
\hline BDE-100 & $0.956^{*}$ & 0.933 & & $1.000 * *$ & $0.998 * *$ & $1.000 * *$ & 0.804 & 0.445 & $0.953 *$ \\
\hline BDE-99 & 0.948 & 0.935 & $0.991 * *$ & & $0.998 * *$ & $1.000 * *$ & 0.807 & 0.450 & 0.945 \\
\hline BDE-154 & 0.887 & 0.864 & $0.977 *$ & $0.987 *$ & & $0.999 * *$ & 0.834 & 0.450 & 0.908 \\
\hline BDE-153 & 0.887 & 0.849 & $0.982 *$ & $0.966 *$ & $0.979 *$ & & 0.814 & 0.443 & 0.888 \\
\hline BDE-183 & 0.046 & -0.041 & 0.314 & 0.260 & 0.392 & 0.487 & & 0.682 & 0.580 \\
\hline BDE-209 & -0.326 & -0.415 & -0.139 & -0.236 & -0.135 & 0.025 & 0.812 & & 0.699 \\
\hline
\end{tabular}

* Correlation is significant at the 0.05 level (2-tailed)

** Correlation is significant at the 0.01 level (2-tailed)

Sed: sediment; Mud: mudsnail

tetra-BDE (BDE-47), tetra-BDE (BDE-47) versus pentaBDE (BDE-99, 100), penta-BDE (BDE-99, 100) versus hexa-BDE (BDE-153, 154) and hexa-BDE (BDE-153, 154) versus hepta-BDE (BDE-183). Besides, the correlation of BDE-209 versus BDE-183 was much higher than that of BDE-209 versus other lower brominated PBDE congeners. This result indicated the metabolism and elimination of PBDEs in mudsnail.

The PBDE congener correlations of mudsnail versus sediment tended to decrease with increasing bromination (Table 4). This maybe due to the biota half-lives of PBDEs decreasing trend with increasing bromination (Huwe and Smith 2007) and the lower bioavailability of higher brominated PBDEs in biota (Martin et al. 2004). The BDE183 correlation of mudsnail versus sediment $(r=0.580)$ was much lower than the correlation of BDE-209 versus BDE-183 in mudsnails $(r=0.812)$, indicated the main source of BDE-183 in mudsnails was from the debromination of higher brominated PBDEs such as BDE-209.
Acknowledgments This study was financially supported by the National Basic Research Program of China (973 Program) (2003CB415005), the Knowledge Innovation Program of Chinese Academy of Sciences (KZCX2-YW-420-3) and the National Natural Science Foundation of China (20437020).

\section{References}

Birnbaum LS, Staskal DF (2004) Brominated flame retardants: cause for concern? Environ Health Perspect 112:9-17

Darnerud PO, Eriksen G, Jóhannesson T, Larsen P, Viluksela M (2001) Polybrominated diphenyl ethers: occurrence, dietary exposure and toxicology. Environ Health Perspect 109:49-68

Huwe JK, Smith DJ (2007) Accumulation, whole-body depletion, and debromination of decabromodiphenyl ether in male spraguedawley rats following dietary exposure. Environ Sci Technol 41:2371-2377

Johnson A, Olson N (2001) Analysis and occurrence of polybrominated diphenyl ethers in Washington State Freshwater Fish. Arch Environ Contam Toxicol 41:339-344

Jonathan V, Rosa AV, Geir WG, Janneche US, Robert JL (2006) Maternal transfer of organohalogen contaminants and 
metabolites to eggs of Arctic-breeding glaucous gulls. Environ Pollut 144:1053-1060

Julander A, Westberg H, Engwall M, van Bavel B (2005) Distribution of brominated flame retardants in different dust fractions in air from an electronics recycling facility. Sci Total Environ 350:51-60

Luo Q, Cai ZW, Wong MH (2007) Polybrominated diphenyl ethers in fish and sediment from river polluted by electronic waste. Sci Total Environ 383:115-127

Mai BX, Chen SJ, Luo XJ, Chen LG, Yang QS, Sheng GY, Peng PG, Fu JM, Zeng EY (2005) Distribution of polybrominated diphenyl ethers in sediments of the Pearl River delta and adjacent South China Sea. Environ Sci Technol 39:3521-3527

Martin M, Lam PKS, Richardson BJ (2004) An Asian quandary: where have all of the PBDEs gone? Mar Pollut Bull 49:375-382

Moon HB, Kannan K, Lee SJ, Choi M (2007) Polybrominated diphenyl ethers (PBDEs) in sediment and bivalves from Korean coastal waters. Chemosphere 66:243-251

Pettersson A, van Bavel B, Engwall M, Jimenez B (2004) Polybrominated diphenylethers and methoxylated tetrabromodiphenylethers in cetaceans from the Mediterranean Sea. Arch Environ Contam Toxicol 47:542-550

Sellström U, Kierkegaard A, de Wit C, Jansson B (1998) Polybrominated diphenyl ethers and hexabromocyclododecane in sediment and fish from a Swedish river. Environ Toxicol Chem 17:1065-1072

Strandberg B, Dodder N, Basu I, Hites R (2001) Concentrations and spatial variations of polybrominated diphenyl ethers and other organohalogen compounds in Great Lakes air. Environ Sci Technol 35:1078-1083

Ueno D, Kajiwara N, Tanaka H, Subramanian A, Fillmann G, Lam PKS, Zheng GJ, Muchitar M, Razak H, Prudente M, Chung K-H, Tanabe S (2004) Global pollution monitoring of polybrominated diphenyl ethers using Skipjack Tuna as a bioindicator. Environ Sci Technol 38:2312-2316

Voorspoels S, Covaci A, Lepom P, Jaspers VLB, Schepens P (2006) Levels and distrbution of polybrominated diphenyl ethers in various tissues of birds of prey. Environ Pollut 144:218-227 